\title{
School meal time and social learning in England
}

\section{Gurpinder Singh Lalli*}

Institute of Education, University of Wolverhampton, Walsall, United Kingdom;

*University of Wolverhampton, Walsall Campus, Walsall, West Midlands, WS1 3BD

Glalli@wlv.ac.uk

ORCID

@Gurpinderlalli

$\underline{\text { Researchgate/Gurpinderlalli }}$

Academia.edu/Gurpinderlalli

Linkedin/Gurpinderlalli 
School meal time and social learning in England

This paper presents an ethnographic account of the culture of school meal time at Peartree Academy, with a specific focus on notions of social learning. This qualitative study is focused on a collection of interviews, observations, field notes and analyses what happens when the school organises its canteen as a restaurant. The focus moves away from the traditional realms of nutrition and explicitly introduces the notion of social learning in its informal sense through which a conceptual framework of a skills model by Dreyfus (2004) is applied. The paper argues how the school dining hall, known as the restaurant can foster opportunities for a form of social competence which is not necessarily seen, but can be experienced in the social reproduction of its actors. The findings highlight tensions of control within the environment, which are said to impinge upon these social learning opportunities from occurring.

Keywords: School meals, social learning, control, educational ethnography

\section{Introduction}

School meals are not merely related to food consumption at school, they are said to be part of the cultural aspect of school life and have an impact on childrens' experiences (Kwon et al., 2018). A number of research studies (Murimi et al., 2016; Falasconi and Vittuari, 2015) have largely focused on the nutritional role of food in education but there appears to be a shortage in research on the social aspect of school meal consumption which is brought to light by Wills et al., (2016) in the work on lunchtime 
surveillance and experiences. An exploration of the social space in which school meals are consumed is of central importance to this paper. The work of Benn and Carlsson (2014) also illustrates how greater consideration must be given to the interaction between pupils and teachers in the context of meal time, which supports the research question (see method section), particularly relating to the importance of teachers' roles in extending a form of sociability. Furthermore, the work of Fossgard et al., (2018) and Leahy and Wright (2016) advocate the need to address the moral discourse in which school meals are situated alongside the importance of sociability. This paper places the concept of social learning in a new context by introducing how teachers in the school come to understand social learning and the tensions which create resistance, preventing informal learning from taking place.

\section{Social learning}

I take social learning in this context to be understood as coming to understand the discourse that emerge about how to behave, such as modelling behaviours of others, using meal time to discuss current affairs, learning how to treat people well alongside avoiding inappropriate gestures or comments. By teacher sociability, reference is made to the function of the instructor in engaging with children during school meal time (Osowski, 2013). Before arriving at the research questions of the study, it is useful to introduce this definition of social learning and discuss its' formulation. Firstly, what is good behaviour at meal times and how is this any different to good behaviour in schools in general? How can one establish whether children are mimicking good behaviour as opposed to negative behaviours? The focus is on training pupils in engaging with social interactions and encouraging positive eating behaviours during meal time as these are distinctly different to behaviours in the classroom, as time devoted to eating can 
potentially lead to the development of social time which can be crucial in forging new eating behaviours (Oostindjer et al., 2016). School meals are a centralised activity and interventions can attempt to equally influence the food behaviours of multiple children concurrently (Oostindjer et al., 2016). It is through these ideas that an attempt is made to inform understandings of social processes in school dining environments.

Peartree Academy ${ }^{1}$ is an all through 3-16 urban school which opened in 2007. The school replaces what was a deteriorating school, in a deprived area of a UK City. According to the latest figures (Department for Education, 2019) it holds a capacity for 1046 pupils with 933 currently enrolled and 272 staff. The school specialises in Business and Enterprise with a focus on food. Local businesses also have involvement within the school, by supplying the ingredients for the school breakfast club as well as sending in their own chefs to teach cookery skills. It is a mixed sex school with a large proportion of pupils of White British heritage. The proportion of pupils supported by the pupil premium is above average. The pupil premium is an initiative which allows schools to gain access to additional government funding in order to support disadvantaged pupils (Department for Education, 2018a), particularly those who are identified as looked after children and/or those who are identified as eligible for Free School Meals $(\mathrm{FSM})^{2}$. FSMs are available to pupils in deprivation which is determined by a set of eligibility criteria (Department for Education, 2018b). A total of 34.2 per cent of pupils at Peartree Academy are eligible for FSM, which is significantly higher than the national average of 13.6 per cent ${ }^{3}$.

\footnotetext{
${ }^{1}$. Peartree Academy was the pseudonym given to the school.

2. National average of Free School Meals (FSM) https://www.gov.uk/government/statistics/schools-pupils-and-their-characteristicsjanuary-2018.

${ }^{3}$ House of Commons briefing paper on the pupil premium: Number 67000, 17 April 2018, by David Foster and Robert Long. http://researchbriefings.files.parliament.uk/documents/SN06700/SN06700.pdf.
} 
In addition to this, $49 \%$ per cent of pupils have Special Educational Needs (SEN) which is above the national average for a school. The restaurant at the school dominates the right hand side of the main building upon entering the reception area. A unique feature of this restaurant is that there are always pupils and staff sitting at tables throughout the school day. The school lunches are staggered amongst all year groups whilst others continue to study. The first impressions of the school restaurant were captured and recorded as field notes, presented below:

It was a frosty winter's morning, at 8 o'clock on 16th January as I approached with some trepidation. The entrance was unusual. On the left, and built as part of the school, was a church. On the right, was the reception where all visitors were asked to sign in to the school. Walking straight ahead and through the doors into the school, I was faced with a surprise. The area that lay in front of me was a wide open space filled with tables attractively grouped to provide seating from small to large numbers of people. On each table stood a small vase of fresh flowers and the whole eating area shone with cleanliness and care. Even though this was before the start of the school day, I saw children eating breakfast, parents talking to one another, a few adults who I assumed to be the teachers chatting in groups, stood around the edge of the dining area. Later in the day, after I talked with the principal, I returned to the dining area, when children were coming in for lunch - Field notes: $16^{\text {th }}$ January 2012

The school restaurant at Peartree Academy is a place for both meeting and eating and can therefore be regarded as a 'learning space', which is defined as a non-discipline specific space frequently used by both staff and pupils for self-directed learning activities (Harrop and Turpin, 2013). It provides opportunities for pupils, staff and parents to mingle, socialise (McCulloch and Crook, 2008) and it is also where informal leaning can take place (Burke, 2005). However, just as elsewhere in the school there are rules and regulations in terms of how that social space is used in order to help pupils in developing as good citizens (Kenreich, 2013). These rules and regulations in part determine the behaviour of staff and pupils during meal times and have an impact upon the social learning that occurs. This paper explores the complex relationship between 
teachers and pupils in relation to social learning. To help provide a lens for understanding social learning, it is imperative to highlight a definition. Jyoti et al., (2005) carried out a study on the impact of food insecurity and define social learning in a way that allows for educational attainment to be measured, which is more so aligned to formal learning as opposed to informal learning.

Osowski (2013) indicates that the school meal is a teaching occasion in which they refer to the notion of the pedagogic meal and this definition is used in the context of school dining halls. The pedagogic meal has been referred to as finding a way to link school food together with learning, with a specific emphasis on teachers' interactions with pupils, but in its more formal sense (Osowski, 2013). For Ahmed (2004), school meals were seen as allowing children to develop opportunities for learning in a social way. Whilst this notion of social learning is not necessarily always seen and able to be measured, it brings to the forefront an important aspect for interpreting the social processes which shape daily meal time consumption. For the purpose of this paper, social learning is about being part of a group and learning about social skills such as how to behave during meal times(Dalton, 2004), which reinforce notions of discipline, conformity and training.

In order to further conceptualise notions of what is meant by social learning, unpacking related terms (i.e. social skills) and one commonly associated theoretical position (Bandura and Walters, 1963) is paramount. For Bandura (1963), according to the social learning view, observational learning occurs through symbolic processes and focuses specifically on questions in relation to how human beings learn behaviour patterns and in this case, how children interact in the school dining hall. In order to extend the 
meaning of behaviourism, relations to include learning from others were introduced in which individuals are able to acquire competence and new patterns of behaviour. Ultimately, the social actors in school dining halls hold a salient position as children observe behaviours which are potentially modelled (Bandura et al., 1961).

Dalton (2004) argues the same social skills are needed by members of society in order to participate. Dalton (2004: 14) defines 'social' as society concerned with mutual relations of human beings, living in organised communities', and 'skill' as 'expertness and practised ability'. The term social suggests that we need some rules by which to live if we are going to get on with those around us. The term skill implies practical knowledge that can be learned and add to the skills acquisition model as posited by Dreyfus (2004), but offers an additional perspective about a measure of being an expert or of having practised something to the point of being expert (Dalton, 2004). As a result, together the term social skills suggests how individuals can have social skills to varying degrees in one aspect of life compared with others but there is a strong relationship with living according to the rules, which are essential for getting along with others. This definition is the most relevant for the purpose of this paper, in which 'social' is defined as being part of an organised community (activity in the restaurant) and 'learning' as including skills which have to be practiced (i.e. positive eating choices and using cutlery appropriately) as well as knowing how to behave in a social context (i.e. good manners, politeness and modelling behaviour). In order to provide a conceptual framework, it is useful to explore the work of Dreyfus (2004) in greater detail. 
It is possible to confuse social skills and social learning behaviour because these are commonly interpreted as synonymous (Bedell and Lennox, 1997). It is important to highlight how social learning is being manifested with or without the teachers' explicit knowledge and for this reason, it is salient to offer definitions. Social skills are the skills employed when interacting with other people at an interpersonal level (Hargie, 1986). Kelly (1982: 3) adds the dimension of learning by defining social skills as those 'identifiable, learned behaviours that individuals use during interpersonal situations to obtain or maintain reinforcement from their environment'. Knowing how to behave in a variety of situations is part of a social skill. In order to better position this idea of skills acquisition, it is useful to consult the work of Dreyfus (2004), who discusses how learners acquire skills through formal instruction and practicing, specifically through a five stage model. At this point, it is essential to note how one can be a novice, or an expert, or anywhere in between and still possess some aspect of the skills (Pena, 2010).

Models are conceptual constructs that seek to embody real things or processes that are said to be hidden for the senses and to the ordinary experience (Pena, 2010). The Dreyfus model highlights how individuals progress in the levels of their acquisition of skills of social knowledge, more specifically in the form of five stages, (1) novice (2) advanced beginner (3) competent (4) proficient (5) expert and master. The first stage of the model suggests how a novice follows rules, does not feel accountable for anything other than following the rules, also how there is a necessity to bring its behaviour into conformity with the rules and finally learning is free of context (Pena, 2010). This framework, particularly the first stage of the model is relevant to the social actors of the school restaurant in which children begin to develop the skills, not necessarily from the starting point of a novice as they would have gained experience of social interaction 
during the elementary stage of school. The emphasis here is on the learning of rules in which power relations are being governed and the findings of this paper relate to notions of discipline and training. It was through the exploration of these concepts of social competence and discipline that helped inform the methodology of this study.

\section{Foucault and Social Learning}

The work of Foucault has been used to interpret the workings of the school meal at Peartree Academy and it is crucial to present three conceptual terms which include discipline, conformity and training. Discipline is defined as a mechanism of power which regulates the behaviour of individuals in what is termed the social body (O'Farrell, 2005: 133). Pupils at the school arguably become agents of their own conformity and the school exercises its strategies and power relations in managing behaviours through training pupils in the school restaurant (Saldana, 2013).

Whilst Foucault has been criticised for failing to offer a rational theory of power (Mills, 2003), the focus of his works is made explicit over time. For example,

First of all, what has been the goal of my work during the last twenty years? It has not been to analyse the phenomenon of power, or to elaborate the foundations of such an analysis. My objective instead, has been to create a history of the different modes by which, in our culture, human beings are made subjects. My work has dealt with three modes of objectification which transform human beings into subjects (Foucault, 1982: 777).

Therefore, it is crucial to draw the link between social learning and the works of Foucault in contextualising this paper, as pupils are learning about conformity in a space which to an extent does require governing through rules and pupils need to be trained in how to behave (Foucault, 1982). 


\section{Methods}

This study was carried out using a social constructivist conceptual framework in which an ethnographic case study approach was adopted (Lalli, 2017a). For Young and Gamble (2006), social constructivism can be described as a product of social practices and state that no knowledge is objective and it is about how a child may come to know a certain world. There is also this idea of time modes when using ethnographic fieldwork and this study adopted a compacted mode (Jeffrey and Troman, 2004) and exploring this is salient in order to detail the research design. It is crucial at this stage to acknowledge how this research is the start of a whole life work and the aim is to develop a long episodic narrative. For instance, to date this ethnographic work begun in 2012 which involved a short period of intense ethnographic research for a six month period. During this period, a concentrated period of time was spent visiting the school, recording field notes, conducting interviews and engaging with both pupils and staff in the school during participating at meal time. Furthermore, the compacted mode (Jeffrey and Troman, 2004) highlights the importance of supporting the authenticity of the research mode by embedding previous ethnographic works.

The influence of previous ethnographic studies, on the lived experiences in schools was instrumental in carrying out this research, as they all accounted for the epistemological positionality of ethnographic research and the degree to which this type of research lends itself to, is presented as one view of the world (Nasirian, 2013; Pike, 2010; Burgess, 1983; Ball, 1981). The research questions of this study are presented below and the focus of this paper is based particularly on the conceptualisation of social learning and it is through researching eating behaviours during meal time that is salient 
in establishing how meanings of social learning are being contested.

\section{Main research question}

What is the impact of the food environment upon social learning?

\section{Subsidiary research questions}

1) How do eating behaviours of staff and pupils impact on social learning?

2) How do teaching staff promote social learning opportunities within a food environment?

Ethnographic interviews, observations and field notes were collated and consisted of 80 hours of semi-structured ad hoc observations (See Appendix 1), 54 semi-structured interviews (See Appendix 2) alongside field notes (See Appendix 3), took place in the school restaurant, the staff rooms and classrooms, taking place between 2013 and 2014. More precisely, it was just meal times that were observed. An opportunity sample of participants who were interviewed included 26 staff, 16 pupils and 12 parents.

Observations were ad hoc and recorded manually in the school restaurant in which field notes were written throughout the school day. A chart was presented in structuring the observations which helped to pin down key situations. The headings used in the table were as follows, (1) situation (2) what was observed (3) thoughts on interpretation of what was happening (4) reflections post observation. The data were analysed using a thematic approach (Boyatzis, 1998) in which coding processes were utilised to group emergent themes.

Ethnographic research is said to be subjective, although this was accounted for as my epistemological influence of being an educationalist of sociology led to adapting a 
robust set of research questions. Whilst ethnographic case study research is said not to necessarily be generalisable, one could argue otherwise, as it is possible for research to be generalisable without it being tied to law-like regularities (Atkinson, 2014).

Moreover, the outcome of ethnographic research encompasses the work of scholars who are acquainted with their own field of specialisation, which is commonly said to be characterised by a mass of ethnographic works and papers. Therefore, ethnographic work does not simply generate thick descriptions of local and spatial features of a given society, but also aims to create concepts which can be applied across a number of social situations (Atkinson, 2014). These discussions have been clearly documented in earlier works (Lalli, 2017a). Having adopted an ethnographic case study approach in an attempt to learn about the lived experiences of those who take part in the school meal, a concentrated view in regards to understanding the space in which meal consumption takes place daily was presented.

Grounded theoretical techniques were adopted through which a thematic analysis (Boyatzis, 1998) emerged based on the set of research questions that were employed in moving this ethnographic research forward (Glaser and Strauss, 1967). Therefore, the work of Boyatzis (1998) was instrumental as it allowed for coding techniques to be adopted. 'Codes identify a feature of the data that appears interesting to the analyst, and refer to 'the most basic segment, or element, of the raw data or information that can be assessed in a meaningful way regarding the phenomenon' (Boyatzis, 1998: 63). For instance, the process involved searching for themes in the form of extraction using a coding approach to induce categories from interview transcripts, observation and field notes (Lalli, 2017a). 


\section{Results}

The findings are split into two distinct parts which address the research questions of this study by highlighting how eating behaviours impact upon social learning in a space in which teachers could be socially engaged with pupils. These parts consist of, (1) rules: structure and control (2) manners: moral development. Findings indicated a discrepancy in what was understood as social learning. Teachers' perspectives are presented and how they understand and interpret social learning. In some of the data, teaching staff refer to this as 'social skills learning'. Therefore, some of the quotations use the phrase social skills rather than social learning. During observations in the school restaurant, a particular focus was placed on how teaching staff interacted with pupils. The most notable observation was that teaching staff were doing more patrolling as opposed to socially interacting.

Following observations, it appeared staff understandings of social learning were questioned throughout the field work. This led to thinking about discipline, conformity and training as teaching staff focused on organising groups of pupils and ensuring they were behaving appropriately during meal time (Saldana, 2013). In this part, the views of five teachers, two teaching assistants, pupil guidance leader, LRC (Learning Resource Centre) leader, an assistant phase leader, senior behavioural leader and the school Principal are presented, all of who have a teaching background. Themes were identified, through commonalities which related to power relations at work such as discipline, conformity and training which are introduced and these are said to impinge upon opportunities for social learning from taking place. 


\section{Rules: Structure and Control}

The teaching staff frequently made links to rules and regulations in relation to the restaurant. Osowski et al., (2013) identified three types of teachers (sociable, educational and evasive) who took part during the school lunch period and identified how it was the educational teacher who led the way for applying rules and procedures whilst interacting with pupils. When questioned about opportunities for social interaction around the school, the response from the assistant phase leader describes how pupils were subject to time constraints during meal times. For example,

'There are a lot of extra-curricular activities; there are a lot of clubs ... after school particularly. The social times we have here are quite short. We only have about 12 minutes break and 30 minutes lunch. So I think primarily, the movement around the school over lunch time is how pupils get time to interact' - Assistant Phase Leader: Wednesday 26th March 2014

The response from the assistant phase leader links to notions of conformity, rules and regulations, which leads to questioning whether the restaurant has been created as a space for this monitoring to take place, or for social learning. She highlighted the structured and controlled nature of the break periods as they were short in duration. Her understanding of social learning did not reflect the one set out by Dalton (2004) as she highlights how break time is restricted, i.e. pupil time, which means time for social learning is limited. She describes opportunities for movement around the school as an opportunity for social learning. For Dalton (2004), social learning involves mutual relations of human beings, living in organised communities and it is about being an expert at living, which is essential for getting along with others.

In relation to being asked about what pupils are learning in the restaurant, the assistant phase leader discusses how to behave and conforming to rules (Saldana, 2013). However, she talks about skills which involve using cutlery appropriately and lining up 
in queues whilst sitting down to eat properly. This relates to social skills such which include eating related behaviours as per the first subsidiary research question. For example,

'Well its learning social skills, it's what they should or shouldn't be doing over a lunchtime period, you know how to line up, how to get to the till, how to behave responsibly, how to act with your peers' - Assistant Phase

Leader: Wednesday 19th February 2014

Occasionally, follow up questions were asked as it was important to clarify responses, particularly relating to social learning. The assistant phase leader, who was also asked, highlighted the importance of instruction in terms of how to help pupils develop social learning in the school restaurant. In her response she talks about lining up, sitting down and learning by example,

'...by instruction and example, it's quite different here because we've got the years right from little so they sort of learn it you know the routine of the restaurant from a tiny little dot, lining up and waiting to go and then we've got them sitting down, we sit down, they sit down, and they're quite close to the older year, because we have a staggered lunch time' - Assistant Phase Leader: Wednesday 19th February 2014

This response demonstrates how the restaurant allows pupils to learn how to behave, although whilst this participant was asked about social learning, she is talking about instruction and learning by example which links to the work of Dreyfus (2004) and the model of competence. She makes the point that pupils learn from one another in the younger year groups. This is about the transitioning period between year groups. In schools, transition has been identified as an important factor in measuring underachievement (Ekins, 2013). More specifically, she talks about uniforms, routine, waiting, sitting down and a staggered lunch period. According to assistant phase leader, the restaurant allows pupils to learn from one another, as per the model presented by Dreyfus (2004) in which levels of competence vary. 
One English teacher also mentions the term 'behaviour' and particularly emphasises the idea of 'establishing patterns of behaviour', rather than referring to social learning. The question that was asked was related to social learning and in his view, pupils learn to interact and behave in which they are being trained to conform. For example,

\begin{abstract}
'Some of the pupils have difficulty with socialisation and it's trying to get them and to gain established patterns of behaviour, establishing norms for how you should behave in certain situations. So apart from the formal academic side of learning, there are also other patterns of learning going on that feed into their normal learning... because they don't know how to behave in the classroom, they don't know how to speak to adults, they don't know how to interact with children their own age, so it's all part of it...' - English Teacher: Wednesday $26^{\text {th }}$ March 2014
\end{abstract}

The English teacher talks about socialisation as a concept but manages to latch on to key words including 'certain situations', 'how to speak to adults', 'interaction' and 'establishing norms'. In schools, there is a growing emphasis on behaviour management meaning socialisation is perceived in a highly individualised and personalised form (Furedi, 2009: 19). Although, by socialisation, the English teacher appears to be discussing social learning, which is not explicitly understood by the teacher. In this case, social learning is being manifested, with or without the teachers' explicit knowledge or ability to articulate such activity. He also makes a reference to behaviour and 'patterns of learning' which differ from formal academic learning. He recognises the restaurant as a venue for social learning. The power relationship at play is the one of conformity and discipline, which is being exercised in a positive way (Saldana, 2013), as pupils are being trained. This notion of norms and value transmission involves using techniques of behaviour management and aligns with the perception of the English teacher and also offers a potential reason for his association of socialisation with the terms 'norms', 'interaction' and 'how to speak to adults'. For example, 
'...because we find that some pupils, if they're below a certain level of socialisation, they can't access the learning anyway, because they don't know how to behave in the classroom, they don't know how to speak to adults, they don't know how to interact with children their own age'English teacher: Wednesday 19th February 2014

It could be argued that the English teacher confuses socialisation with social learning, although this suggests one way in which social learning is being manifested as a concept. He makes links to how pupils need to learn certain patterns of behaviour dependent on the situation in which they find themselves. Other research argues that, ultimately teachers are responsible for the pupils' welfare, 'which includes their physical, emotional and social wellbeing' (McCulloch and Crook, 2008: 453). On this basis, the English teacher has a good understanding of social learning and he demonstrates the importance of pupils needing to learn about the eating behaviours which are bound by rules, so this is evidence of the type of learning taking place. The idea being that whilst pupils are negotiating the rules and regulations of the dining hall. Ultimately, it is the teachers who are able to take opportunities to mould pupils through socially interacting and establishing when and when not to enforce these rules.

\section{Manners: Moral Development}

This part highlights how manners and dining etiquette are central to what is being learnt during meal times so pupils are being trained. Another common theme that emerged from the findings was about table manners and moral development. It is about recognising the importance of teaching pupils about how to behave at meal time whilst modelling good eating behaviours as discussed by Birch (1980) and Eliassen (2011). In this example below, one teacher points out how saying 'please' when in the restaurant is a form of social learning, but interesting one of the teachers glances towards me and suggest how this pupil is demonstrating use of a social skill, for example, 'See...that is 
a social skill!'. In this case, pupils are learning about manners so a form of training is shaping their meal time experiences.

One example from my observations highlighted how pupils commented on each other's puddings and in this way, they are practicing positive manners whilst exercising eating behaviours through describing the aesthetics as they highlight textures and characteristics in taste. This links to the work by Rahim et al., (2012) and Eliassen (2011) who make links between school food and manners in terms of how pupils are able to exercise good manners during meal time. This teacher's knowledge of the research and how it is concerned with social learning also begins to surface as she looks towards me for reassurance. Therefore, this example indicates that manners, including please and thank you, are understood by this teacher as a form of social learning.

The response from the science teacher below offers another view of social learning. In this case, he talks about the displays on the wall; respect and forgiveness as forms of moral development. It is useful to consider changes to the school dining environment which were discussed by Rudd et al., (2008), who found that pupils responded positively to changes to the dining environment which included alterations to the aesthetics. The study by Rudd et al., (2008) considered the views of pupils before and after the renovations. There is something to be said about the wall displays in the school restaurant at Peartree Academy and links between social learning and wall displays are explicitly discussed by the Science teacher in support of this notion. For example,

'...they can learn social skills...which are also displayed on the walls. You've got posters, when they're eating, most time, they're facing the dinner ladies or dinner men, whoever is serving, they've got stuff to read around to do with respecting you know, forgiveness and they can read around that area'-Science Teacher: Wednesday 26th March 2014 
He assumes that the pupils actually read the posters and did not simply see it as wallpaper. While the intentions of the school may have been to encourage moral and social development through the poster displays, the evidence does not support this as an effective approach and therefore, this is due to recognising that pupils need physical beings to train them as opposed to signage. More specifically, sufficient evidence through observation was not able to determine how pupils were affected by these messages. This example demonstrates that active modelling of behaviour was a more appropriate position in terms of social learning (Pena, 2010).

The Principal discusses a number of factors in relation to social learning in the school restaurant, but here, she presents a similar response to that of the Deputy Principal who also talks about manners and moral development synonymously with social learning. The Principal describes the responses of visitors to the school and the manners pupils display when visitors are present. For example,

'...skills around even using a knife and fork, manners, developing healthy eating skills, developing social skills...I have lots of visitors to this academy, our Year 10 and 11 in particular are exceptional in their manners, they can sit there for a good 20 to 25 minutes and they are impeccably well behaved because they've learnt how to use social time in that way. I think whatever we're thrown in teaching people manners, in that restaurant at lunch time; it serves up every opportunity...' - Principal: Thursday 19th June 2014

The Principal is talking about manners and how visitors perceive the view of the restaurant. The point that she is describing 'exceptional manners' as being able to sit in the restaurant for twenty to twenty-five minutes, whilst using a knife and fork properly suggests that firstly pupils are learning how to behave, which is a way pupils are being trained. The argument she presents does have value in relation to social learning but it is also due in parts to disciplining pupils in terms of behaviour. She refers to skills pupils acquire, making reference to pupils leaning about manners. The Principal suggests that 
pupils are being controlled in their environment. By discipline, reference is made to the mechanism of power which regulates the behaviour of pupils (O'Farrell, 2005).

The pupil guidance leader describes how pupils are learning about social skills, manners and also how to eat. She discusses how pupils are encouraged to help them develop autonomy. This is about developing positive eating behaviour as discussed by Eliassen (2011). She provides her perception of how pupils are using the restaurant for social learning in this way. For example,

'...they're learning social skills... also manners, and eating skills cutting up food and just general table manners...I always encourage them to show how to set a good example to the children. I always encourage them to help them with the food but to encourage the children to do it for themselves, help them learn...' - Pupil Guidance Leader: Wednesday 9th February 2014

She highlights how pupils are encouraged by midday supervisors to set good examples, particularly in terms of food choices and table manners. This is also discussed by Eliassen (2011), who links eating behaviour to role modelling. Bergh (2014) identifies with the importance of trying to create an environment which is similar to the home.

The Deputy Principal identifies how pupils are able to learn how to use the right cutlery. He pointed to meal time experiences for some of the pupils who he claimed did not have access to a 'proper meal'. Janhonen et al., (2013) provided one view of a proper meal, which was considered as structural and most common when describing meals for the family. He identified how pupils were using lollipop sticks to pick up the chicken breast instead of using a fork. For example,

'...early on I saw some kids, 12, 13 year olds, with a chicken breast with a fork and lollipop stick because they're not used to using a knife and fork...so all those are good things because we get a lot that, they don't have tables at home, get them to sit around a table and actually have proper 
home cooked meal...'- Deputy Principal Finance and Resources:

Wednesday 26th March 2014

According to the deputy principal, pupils did not always have access to a dining table at home and were not familiar with how to use a knife and fork, although this raises questions of appropriateness as culturally, it may well be difficult to determine what is appropriate with regards to dining etiquette. For instance, the acquisition of table manners is an important aspect of food socialisation and cuisine is not that simple as there are many senses of appropriateness that are to be considered (Cohen et al., 2019). Whilst it is difficult to find evidence to support his claim, he does identify with the school restaurant as a space for interacting, although cutlery skills in children have been identified as a problem area (Piercy, 2008).

The senior behavioural leader was also in agreement with the Deputy Principal and highlights how some of the older pupils often struggle with using cutlery. It is said that with the shift towards a fast food culture, children have not been able to develop cutlery skills (Piercy, 2008). He illustrates by drawing on his experience of how this is affecting pupils in which he makes the statement of how pupils in year 10 (age 14-15), struggle with using cutlery appropriately. This links back to the research questions presented in this study as eating behaviours are being addressed.

The Assistant Principal also describes how pupils struggled to use cutlery and points out how the school spent a considerable amount of time teaching pupils about table manners, prior to her appointment at the school which illustrates the importance of training pupils (Saldana, 2013) with the appropriate skills in order to survive within this particular environment. For example, 
'...before I came they spent a lot of time actually teaching children to have those table manners really and a lot of the children weren't able to use knives and forks properly' - Assistant Principal, Phase 1: Wednesday 19th February 2014

Therefore, there is evidence to suggest that pupils are learning the very basic skill of how to use cutlery in the school restaurant. This emphasises the importance of the role of food in education (Kaklamanou et al., 2012). More importantly, citizens as a collective have a huge responsibility in forging eating behaviours for the rest of their adult lives and those in the school restaurant who are modelling this behaviour are tasked with ensuring pupils are able to gain exposure to that type of behaviour.

The Assistant Principal discusses how pupils are learning about politeness and presented with opportunities to make healthy food choices. Andersen et al., (2016) highlight how children's food choices are affected by the way in which the food environment has been developed. She describes how the restaurant allows for the opportunity of sharing food together. For example:

'...I think through the restaurant and through the opportunity to share food. I know at the beginning it was a real focus for the academy, so there was a really big focus...encouraging them to be polite really and social to each other at the table...-Assistant Principal, Phase 1: Wednesday 19th February 2014

This point illustrates how the restaurant encourages pupils to be polite and social although this is not described any further. Lucy identifies how lunch time staff are supporting pupils by encouraging social behaviour and to be polite. This links to the works of Foucault in which pupils are being trained (Saldana, 2013) to conform for their own benefit, in shaping them to become good citizens. 
The senior behaviour leader discusses how pupils are able to learn about what is acceptable behaviour and social cues, particularly how manners are being acquired. The work of Dreyfus (Pena, 2010) is particularly noteworthy here is this is about social competence and being able to exercise or develop these skills from one level to the next. For example,

'the key social cues that they may not already have, so it's that wider life skill learning you know, what's acceptable in a restaurant, what's acceptable around a dinner table, how you conduct yourself around other people when you're eating you know...they're key social skills that everybody needs. And also then you are teaching them about different foods and what, it's an opportunity to you know say why you should eat this food and model these behaviours' - Senior Behaviour Leader (Whole-school): Wednesday 19th February 2014

He also draws on the importance of teaching pupils about how to behave during meal time and modelling eating behaviours (Birch, 1980; Eliassen, 2011). He makes links with what to eat as well as how to eat as important factors all contributing to a healthy school experience. Lindon identifies the responsibility of both staff and pupils, who are in a position of modelling social behaviour by eating with each other, minimising behavioural difficulties whilst developing opportunities to interact in a social way. For example,

'what sort of table etiquette, what's right what's wrong. About sharing and waiting their turn, we don't generally have problems with them, you know when you've got a whole group going down for lunch and there's all those people that you don't get problems with people jumping the queues' - LRC (Learning Resource Centre) Leader: Wednesday 19th February 2014

There are two lines of argument in what is said by the LRC leader. Firstly, that the restaurant is a place where social learning takes place in the form of learning about 'table etiquette', but then, secondly she makes the link to right and wrong. The evidence above lends itself to the moral development of pupils and refers to this as a form of social learning. It is about 'expertness' and the ability to get along with other pupils in 
the school restaurant. Dalton (2004) describes how this expertness emerges through practised ability and Rochelle highlights this when talking about achieving independence in pupils.

Overall, it is evident that staff perceive social learning in different ways, in that their understanding is limited. The correlations gleaned from this section highlight the perceptions of the teaching staff. When discussing social learning, teachers appear to be referring to three common themes, which include rules, conformity and manners. Therefore, rather than interacting with pupils in a social context, teaching staff seem to be predominantly concerned with monitoring pupil behaviours and enforcing rules. Ultimately, time spent in the dining area is a time for interaction, sociability and a form of self-discipline (Lomax, 1999).

Whilst teaching staff also make reference to these areas, they tend to focus predominantly on rules and regulations. On balance, teaching staff appear to have a limited understanding of social learning and are focused on disciplining pupils as opposed to teaching pupils specific skills and encouraging social learning. There seems to be some discrepancies in their understanding of social learning, although one of the primary functions of teacher training gears newly qualified instructors to manage and control groups and a shift in a focus towards capitalising on spaces outside of the classroom need to be exploited (Lomax, 1999). Furthermore, when questioning teaching staff about social learning, they refer to rules, working together and manners, linking closely to behaviour. Whilst Dalton (2004) would argue that rules are important in getting along with others in society, the restaurant as a space for developing social skills 
could be a good pedagogical learning opportunity. However, some of it is being missed because the staff do not understand what sort of social learning could be encouraged.

\section{Discussion}

Findings gleaned from this paper draw out correlations between how teaching staff understand social learning and how pupils as the social actors of the restaurant are negotiating the rules which govern this space. To return to the initial questions posed at the beginning of this paper, social learning does appear to be taking place, based on the data being presented, but it is imperative to note that whilst staff may be modelling appropriate eating behaviours and pupils are exposed to such behaviours, these are not necessarily seen behaviours, meaning that pupils are also trained to conform to the norms and social rules of the school dining environment. In this sense, there are potentially overt actions and relationships which are observable, but more so a hidden conscious or unconscious agenda of power and rules which are being exercised. Although, these power relations are not necessarily a negative phenomenon as pupils need the relevant life skills of being able to socialise with one another to survive in society, but there are certainly tensions in which teaching staff could be said to take better advantage of these opportunities of socialising with pupils in the restaurant. The initial discussion introduced what was meant by social learning, by drawing on the works of Dalton (2004) and a more robust model presented by Dreyfus. When referring to social learning, teaching staff make reference to three common areas which included, 1) rules and regulations 2) how to behave 3) manners: moral development. Overall, clearly the school dining environment can arguably become a site for such informal learning practices to take shape, although the patrolling of the restaurant can sometimes prevent social learning from taking place. 


\section{Limitations}

Having touched on notions of appropriateness (Cohen et al., 2019) earlier in the paper alongside the complexity of not necessarily being able to establish behaviours that can be seen, it is useful to explore these as limitations to the study in moving forward. Furthermore, considering the ethics of eating practices surrounding children and families (Punch et al., 2013) can also lend itself to much scrutiny in the way in which findings have been presented in this paper. For instance, the culture value attached to the 'proper family meal' is based on a sociological construction of the family meal as a 'universal, regularly practiced, stable event', which has been identified as a historical myth (Jackson et al., 2009: 144). For this reason, highlighting these particular issues are paramount, particularly for moving the field of social learning in the context of meal time consumption in schools forward. For those who study behaviour consider learning in its broad sense and this could occur even if they do not necessarily recognise it as changes in behaviour can be subtle and consequentially changes take place over time (Broom, 2009). Therefore, social learning may not necessarily be seen at this moment in time as learning is not episodic but occurs continuously, which means behaviour is not affected immediately (Broom, 2009). Furthermore, whilst some teachers appear to confuse socialisation and social skills with social learning, it was not explicitly stated by participants and further research which explores this aspect would be crucial in supporting teachers' recognition of such an activity.

\section{Conclusion}

Overall, this paper presents an argument to suggest how social learning is taking place in some instances, although power relations are in play which has led to linking to the works of Foucault and power relations. To return to the research questions of this study, 
firstly it is useful to consider the impact of eating behaviours in enhancing pupils meal time experiences and this has been evident as pupils are able to situate themselves in a space which facilities social learning opportunities. Second, teachers are showing some examples of how interacting with pupils at meal times can enhance the school meal experience in which pupils are trained. A better understanding of social learning could be instrumental in which teachers could be trained to help shape and make the most from informal learning opportunities with pupils, but the teaching staff and make little reference to social competence and are said to be teaching pupils about the rules and

regulations of how to behave in a dining hall. So, it is important to consider what could be done to help tackle this missed opportunity for social learning. One argument is that schools could prioritise the dining space so that it is conducive for social learning and additionally train staff. There are still differences in perceptions of social learning for teaching staff in schools, which has been evident in my work on school meals across a number of educational establishments, although the complex nature in which the school meal exists means it can be difficult for teachers to move beyond a disciplinarian position. In addition, aside from the findings on social learning, the exploration and exposure on social skills as a concept adds to the contribution of this paper. The other limitation is that this type of informal learning cannot necessarily be seen is also paramount in being able to position this research and any future related research on school dining halls would need to consider these methodological implications in attempting to demystify school meal research.

\section{Acknowledgements}

I would like to acknowledge both reviewers for providing critical commentary on this paper, for which I am grateful. 


\section{Funding}

Financial support for this study was received from University of Leicester and the Peartree Foundation.

\section{ORCID}

Gurpinder Singh Lalli https://orcid.org/0000-0002-7493-4813

\section{Declaration of interest statement}

Gurpinder Singh Lalli declares that he has no conflict of interest and that the research follows the University of Leicester's code of ethical practice and meets the requirements of the Human Subject Research (HSR) with children. All research conducted was carried out appropriately in conjunction with the HSR and British Educational Research (BERA, 2018) guidelines.

\section{References}

Ahmed, A. U. 2004. Impact of feeding children in school: Evidence from Bangladesh, International Food Policy Research Institute, Washington DC.

Andersen, S. S., Vassard, D. Havn, L. N., Damsgaard, C. T., Biltoft-Jensen, A., \& Holm, L. 2016. Measuring the impact of classmates on children's liking of school meals. Food Quality and Preference, 52, 82-95.

Atkinson, P. 2014. For Ethnography, London: Sage Publications. 
Bandura, A. and Walters, R. H. 1963. Social Learning and personality development. New York: Holt Rinehart and Winston.

Bandura, A., Ross, D., Ross, S. A. 1961. Transmission of aggression through the imitation of aggressive models. Journal of Abnormal and Social Psychology, 63, 575582.

Benn, J. and Carlsson, M. 2014. Learning through school meals. Appetite, 78, 23-31.

Boyatzis, R. E. (1998) Transforming qualitative information: Thematic analysis and code development. London: Sage Publications.

Broom, D. (2009) Biology of behaviour: Mechanisms, functions and applications. Cambridge: Cambridge University Press.

Burgess, R. 1983. A study of Bishop McGregor School - Experiencing Comprehensive Education. London: Methuen \& Co. Ltd.

Ball, S. J. 1981. Beachside Comprehensive: A case-study of secondary schooling. Cambridge: Cambridge University Press.

Bedell, J. R. and Lenox, S. S. 1997 Handbook for communication and problem-solving skills training: A cognitive-Behavioural Approach, New Jersey: John Wiley \& Sons. 
Bergh, A. 2014. Sweden and the revival of the capitalist welfare state. Cheltenham: Edward Elgar Publishing.

Birch, L. L. 1980. Effects of peer models' food choices and eating behaviours on preschoolers' food preferences. Child Development, 51, 489 - 496.

Burke, C. 2005. Contested desires: The edible landscape of school. Paedogoica Historica: International Journal of the History of Education, 41(4), 571-587.

Cohen, D. and Kitayama, S. (Eds.). 2019. Handbook of cultural psychology (2 ${ }^{\text {nd }}$ ed.). New York: Guildford Press.

Dalton, T. A. 2004. The food and Beveridge handbook. Cape Town: Juta Academic. Department for Education (2019) Peartree Academy, Retrieved from http://www.education.gov.uk/cgi-bin/schools/performance.

Dreyfus, S. E. 2004. The five-stage model of adult skill acquisition, Bulletin of Science, Technology and Society, 24 (3), 177-181.

Department for Education. 2019. Peartree Academy Demographics, Retrieved from http://www.education.gov.uk/cgi-bin/schools/performance.

Department for Education. 2018a. Pupil premium: Funding and accountability for schools, Retrieved from https://www.gov.uk/guidance/pupil-premium-information-forschools-and-alternative-provision-settings. 
Department for Education. 2018b. Free school meals guidance, Retrieved from https://www.gov.uk/government/publications/free-school-meals-guidance-for-schoolsand-local-authorities.

Durlak, J. A. and Weissberg, R. P. 2007. The impact of after-school programs that promote personal and social skills. Centre for Academic, Social and Emotional Learning (CASEL). Retrieved from http://www.lionsquest.org/pdfs/AfterSchoolProgramsStudy2007.pdf

Ekins, A. 2013. Understanding and tackling underachievement. London: Optimus Education.

Eliassen, R. K. 2011. The impact of teachers and families on young children's eating behaviours. Young Children, 66(2), 84-89.

Falasconi, L. and Vittuari, M. 2015. Food waste in school catering: An Italian case study, Sustainability, 7, pp. 14745-14760.

Fossgard, E., Wergedahl, H., Bjorkkjaer, T., Holthe, A. 2018 School lunch-Children's space or teachers' governmentality? International Journal of Consumer Studies, 42(6), $1-9$.

Foucault, M. 1982. The subject and power: afterword to Dreyfus, H. and Rabinow, P. in Dreyfus and Rabinow, P. Michel Foucault: Beyond structuralism and hermeneutics, Chicago, Illinois: University of Chicago Press. 
Furedi, F. 2009. Socialisation as behaviour management and the ascendancy of expert authority. Amsterdam: Amsterdam University Press.

Jackson, P., Olive, S., \& Smith, G. 2009. Myths of the family meal: re-reading Edwardian life histories, in P. Jackson ed. Changing Families, Changing Food. Basingstoke: Palgrave Macmillan, 131-45.

Jeffrey, B. and Troman, G. (2004) Time for ethnography, British Educational Research Journal, 30(4), pp. 535-548.

Glazer, B. and Strauss, A. 1967. The discovery of grounded theory analysis, Mill Valley, California: Sociology Press.

Jyoti, D. F., Frongillo, E. A., Jones, S. J. 2005. Food Insecurity Affects School Children's Academic Performance, Weight Gain and Social Skills. American Society for Nutrition, 135(12), 2831-2839.

Hargie, O. 1986. Social skills training and psychiatric nursing. Croom Helm: London. Hart, C. S. 2016. The school food plan and the social context of food in schools. Cambridge Journal of Education, 46(2), 211-231.

Harrop, D. and Turpin, B. 2013. A study exploring learners' informal learning space behaviours, attitudes and preferences. New Review of Academic Librarianship, 19(1) $58-77$. 
Hendy, H. M. and Raudenbush, B. 2000. Effectiveness of teacher modelling to encourage food acceptance in preschool children, Appetite, 34(1), 61-76.

Janhonen, K., Benn J., Fjellstrom, C., Makela, J., Palojoki, P. 2013. Company and meal choices considered by Nordic adolescents. International Journal of Consumer Studies, 37(6), 1470-6423.

Kaklamanou, D. Pearce J. Nelson, M. 2012. Food and academies: a qualitative study, Research Report, School Food Trust, Department for Education. Retrieved from https://www.education.gov.uk/publications/eOrderingDownload/Food\%20and\%20Acad emies\%20-\%20a\%20qualitative\%20study.pdf

Kelly, J. A. 1982. Social skills training: A practical guide for interventions. New York: Springer.

Kenreich, T. W. 2013. Geography and social justice in the classroom, London: Routledge.

Kwon, S., Kim, O., Lee, Y. 2018. Effects of students' satisfaction with school meal programs on school happiness in South Korea. Nutrition Research and Practice, 12(4), 342-347.

Lalli, G. 2017a. The Restaurant: A social learning space? An ethnographic case study of an Academy school. (Doctoral dissertation). University of Leicester: Leicester, UK. 
Lalli, G. 2017b. Commensality and the School Restaurant. British Education Studies Association: Educational Futures, 2(8), 69 - 88.

Leahy, D. and Wright, J. 2016. Governing food choices: A critical analysis of school food pedagogies and young people's responses in contemporary times. Cambridge Journal of Education, 46(2), 233-246.

Lomax, P. 1999. Working together for educative community through research (Presidential Address, Belfast, August 1998), British Educational Research Journal, 25, $5-21$.

McCullough, M. B. and Hardin, J. A. 2013. Reconstructing obesity: The meaning of measures and the measure of meanings, Oxford: Berghahn Books.

McCulloch, G. and Crook, D. (Eds.). 2008. The Routledge International Encyclopedia of Education. London: Routledge.

Mills, S. 2003. Michel Foucault. New York: Routledge.

Murimi, M. W., Chrisman, M., McCollum, H. R., Mcdonald, O. 2016. A qualitative study on factors that influence students' food choices, Journal of Nutrition and Health, $2(1), 1-6$.

Nair, P. and Gehling, A. 2008. Democratic school architecture, Voices in Urban 
Education, Annenberg Institute for School Reform, 34, Retrieved from http://vue.annenberginstitute.org/sites/default/files/issuePDF/VUE19.pdf

Nasirian, Y. 2013. How children in Cape Verde experience school meals: an ethnographic study, Food Service Management Report VT12-71. Retrieved from https://gupea.ub.gu.se/bitstream/2077/33092/1/gupea_2077_33092_1.pdf

O’Farrell, C. 2005. Michel Foucault. London: Sage Publications.

Oostindjer, M., Aschemann-Witzel, J., Wang, Q., Skuland, S. E., Egelandsdal, B., Gro V., Amdam, Schjoll, A., Pachuki, M. C., Rozin, P., Stein, J., Almli, V. L., Kleef, E. V. 2016. Are school meals a viable and sustainable tool to improve the healthiness and sustainability of children's diet and food consumption? A cross-national comparative perspective, Critical Reviews in Food Science and Nutrition, 57(18), 3942-3958.

Osowski, C. P., Goranzon, H., Fjellstrom, C. 2013. Teachers' interaction with children in the school meal situation: The example of pedagogic meals in Sweden. Journal of Nutrition Education and Behaviour, 45(5), 420-427.

Pena, A. 2010. The Dreyfus model of clinical problem-solving skills acquisition: A critical perspective. Medical Education Online, 15(1), 1-11.

Piercy, N. 2008. Market-led strategic change. London: Routledge.

Pike, J. 2010. An ethnographic study of lunchtime experiences in primary school dining rooms. (Doctoral dissertation). University of Hull: Hull, UK. 
Punch, S., McIntosh, I., Emond, R. (2013) Children's food practices in families and institutions. London: Routledge.

Rahim, N., Kotecha, M., Callan, M., White, C., Tanner, E. 2012. Implementing the Free School Meals Pilot, RR228. Department for Education. Retrieved from https://www.education.gov.uk/publications/eOrderingDownload/DFE-RR228.pdf

Rudd, P., Reed, F., Smith, P. 2008. The effects of the school environment on young people's attitudes towards education and learning, Summary Report, National Foundation for Educational Research.

Saldana, J. 2013. Power and conformity in today's schools, International Journal of Humanities and Social Science, 3(1), 228-232.

Stevens, L. Oldfield, N. Wood, L. Nelson, M. 2008. The impact of primary school breakfast clubs in deprived areas of London. School Food Trust, Eat Better Do Better.

Young, M. and Gamble, J. 2006. Knowledge, Curriculum and Qualifications for South African Further Education, Cape Town: HSRC Publishing.

Wills, W., Danesi, G., Kapetanaki, A. B. 2016. Lunchtime food and drink purchasing: Young people's practices, preferences and power within and beyond the school gate. Cambridge Journal of Education, 46(2), 195-210. 


\section{Appendices}

Appendix 1 - Observation

Observation chart

\begin{tabular}{|l|l|l|l|l|}
\hline $\begin{array}{l}\text { Period/ } \\
\text { Situation }\end{array}$ & $\begin{array}{l}\text { Year } \\
\text { Group }\end{array}$ & $\begin{array}{l}\text { What I have } \\
\text { observed }\end{array}$ & $\begin{array}{l}\text { Why I think this } \\
\text { has happened }\end{array}$ & Further thoughts \\
\hline Lunch & $\begin{array}{l}\text { Younger } \\
\text { Year } \\
\text { Pupils }\end{array}$ & $\begin{array}{l}\text { Pupils make } \\
\text { their way } \\
\text { into the } \\
\text { restaurant } \\
\text { towards the } \\
\text { buffet area } \\
\text { as usual. }\end{array}$ & $\begin{array}{l}\text { General } \\
\text { conversation } \\
\text { between pupils, } \\
\text { which I am } \\
\text { unable to hear } \\
\text { due to noise } \\
\text { levels and } \\
\text { privacy. }\end{array}$ & $\begin{array}{l}\text { Beginning to recognise } \\
\text { the practicality of } \\
\text { observing during the } \\
\text { morning session compare } \\
\text { with the lunch hour. } \\
\text { Clearly, it is easier to } \\
\text { record conversations and } \\
\text { interactions prior to the } \\
\text { lunch period, purely based } \\
\text { on noise pollution. }\end{array}$ \\
& & & \\
\hline
\end{tabular}

\section{Appendix 3-Field Notes}

\subsection{0am}

On the first day of the observations, I made myself familiar with some staff and also was approached by pupils, who welcomed me to the school. I positioned myself in the corner of the restaurant, next to the dustbin, buffet stand, where I had a view of the whole restaurant. I can see the staff room, situated diagonally from my position, reception area to my left. Although lunch has not started, I thought it would be a good idea to settle in, whilst trying not to look like a member of the OFSTED team. In my favour, there were staff members who sat in the restaurant with colleagues and pupils before lunch. Although meetings were brief between staff, the restaurant seemed to be utilised constantly. There were small groups of staff who would regularly sit and chat away...

Appendix 2 - Interviews

Interview questions for school staff

Questions:

1. What influenced your decision to join the school and how long have you been teaching or working at the school?

2. Outside of the classroom, how are pupils able to develop their social skills?

3. What's your experience of dining halls in schools? What makes this different?

4. What's the school regulation on school food in the classroom? Do they eat in your lessons? Do you think that helps them concentrate on what they're doing? What do you allow? Is this a rule?

5. What extra activities does the school provide that have a positive impact on learning? For example, during break and lunch times.

6. How does the breakfast club help pupils? 
7. In what ways do children continue to learn during the time in the restaurant? What sort of things are they learning? How is that happening?

8. Do you spend much time in the restaurant? If yes, what do you do?

Interview questions for pupils

Questions:

1. What is your favourite school meal?

2. What is your favourite school drink?

3. What do you think about the school restaurant?

4. Where do you eat dinner at home?

5. Do you have school breakfast?

6. Apart from eating food, what do you do like/dislike in the restaurant?

Interview questions for parents

Questions:

1. What influenced your decision to send your child/children to the school?

2. What do you think about the school restaurant?

3. Do you make use of the school restaurant? If yes, how?

4. Do you think it matters what your children eat in the restaurant? Why? 